\title{
Perception of 'English' and Motivation in Learning English
}

\author{
Mehmet Şahin ${ }^{1}$, Şule Y. E. Seçer ${ }^{1}$, Yavuz Erişen ${ }^{1}$ \\ ${ }^{1}$ Yıldız Technical University, Faculty of Education, Istanbul, Turkey \\ Correspondence: Mehmet Şahin, Yıldız Technical University, Faculty of Education, Istanbul, Turkey.
}

Received: May 16, 2016 Accepted: June 1, $2016 \quad$ Online Published: June 12, 2016

doi:10.11114/jets.v4i9.1672ＵRL: http://dx.doi.org/10.11114/jets.v4i9.1672

\begin{abstract}
This study aims to present high school students' perception of "English" through the impressions and images and the effect of these perceptions on their motivation in learning English. This qualitative study is based on the data about students' metaphors and the focus group interview to determine their effect on the students' motivation. The research group for metaphors consists of 128 high school students from four different grades. 79 metaphors were collected and grouped under 12 categories. In addition, two different focus group interviews are held with 7 students having negative and positive perspectives to determine the effect of these perceptions on students' motivation in learning English. According to the analysis of the data from focus group interviews, students mostly perceive "English" as a target language to learn rather than a foreign language, spoken by a definite society or belonging to a culture. The results of metaphor study also indicate that the students regarding "English" positively tend to have a higher participation and motivation in comparison to the students having negative perceptions.
\end{abstract}

Keywords: culture, English, learning, metaphor, perception

\section{Introduction}

\subsection{Culture and Language}

When "culture of a society" is considered, one of the first concepts that comes to mind is "language". Since language can be accepted to be the common instrument to convey meaning through communication, it is an inseparable part of culture. In addition, all human history, there existed lots of languages and cultures, conveyed beneath or via these languages. According to Bennett (1993:9) learning a language without its culture is a recipe for becoming "a fluent fool and a fluent fool is someone who speaks a foreign language well, but does not understand the social or philosophical content of that language. When the interrelation in between these two inseparable concepts is taken into consideration, it can be said that culture is embedded in language. Hence, great importance should be placed on the teaching of culture in the language classroom. Politzer (1959:99) argues that when a language is taught as a separate entity from its culture, it turns out to be a mere group of meaningless symbols which are too complicated for the learners to elicit any meaning from. Therefore, while teaching a language without any cultural references or meaning, one may know the language but he/she may not be successful in learning and using the target language due to lack of cultural knowledge or background. Brown (1994:165) describes the relation between language and culture and states that a language is a part of a culture and a culture is a part of a language; the two are intricately interwoven so that one cannot separate the two without losing the significance of either language or culture.

\subsection{The Significance and Purpose of the Study}

The effect of perceptions on the motivation in learning English is regarded as an important problem. For this, what metaphors language about the concept of "English" and why they think like that is to be understood for the determination of effective teaching methods and techniques. In addition, how the learners' negative and positive perceptions of "English" affect their participation in the learning activity and how they are motivated are important factors to be considered in learning English.

It is a general impression and also a matter of confusion that English language is directly related to English people and culture by the English language learners. Impression or mental images are determined mainly by the formation of metaphors. Metaphor is a simple technique to collect data on perceptions especially of young students at early ages. 
The purpose of this is to investigate high school students' perception on metaphoric of "English Culture". Also, this study aims to explore the effects of these perceptions on the motivation in learning English. Within this main purpose of this study, the following questions are inquired:

- What metaphors do high school students construct about the concept of "English"?

- How do students' negative and positive perceptions of "English" affect their participation, and motivation in learning English?

\section{Material and Method}

\subsection{Metaphor Technique}

This paper is a based on a descriptive research in qualitative design. In order to find out how high school students perceive "English", metaphor technique is used as a data collection instrument. Basically, the meaning of metaphor is to explain a complex phenomenon or event by likening it to another phenomenon or event (Oxford et al., 1998). Aristo (2008:59-60) also defines metaphor as assigning a word a meaning other than its specific meaning which is possible by attaching the meaning of gender to kind, the meaning of kind to gender or the meaning of kind to another gender or according to a proportion. According to Sennett (1980:78) "a metaphor creates a meaning greater than the sum of its parts". In addition, Saban (2004) defines metaphor as a process of building linkages between knowledge in mind which make it possible to perceive and understand from the perspective of another subject. Shuell (1990:102) writes: "If a picture is worth 1,000 words, a metaphor is worth 1,000 pictures. For a picture provides only a static image while a metaphor provides a conceptual framework for thinking about something". While Eraslan (2011) praises metaphor as a perfect technique to teach unknown things and a valid tool to store in mind and remember the knowledge acquired Sezer (2003) explains metaphorical thinking process in following stages:

- An abstract phenomenon (situation, event, concept) intended to be explained and made sense of,

- A concrete and explicit phenomenon used to explain this phenomenon and linguistic expression of this phenomenon,

- Specific equivalences and analogies formed between these two phenomena.

On the other hand, Balc1 (1999) claims that metaphorical thinking process is composed of two parts as "topic" and "vehicle". While topic refers to a phenomenon, situation or concept explained or meant to be explained, vehicle refers to a term or terms used metaphorically (p.33). When the literature is examined, it is seen that metaphors have been studied many times since 1980s in different disciplines of social and educational sciences. In Turkish research studies of Çelikten (2006), Saban (2009), Aydın (2010), and Eraslan (2011), several metaphors were formulated about "culture", "teacher", "student", "school", "sociological" and "leadership"

\subsection{Focus Group Interview}

The second aim of the research is to find out how students' negative and positive perceptions of "English" affect their participation, and motivation in learning English. For this purpose, focus group interview is used as a secondary instrument for data collection in order to explore the effect of these perceptions on their motivation in learning English. The metaphor study is applied on 128 students consisting of two sections from each of four grades in the state high school where the researcher is an instructor of English as well. The participants of the focus group interviews are seven students, four of whom have the even numbers in the group of students who construct positive metaphors and three of whom have the odd numbers in the sequence of students who construct negative metaphors.

\subsection{Participants}

The participants of the metaphor technique use include 128 students attending a state high school in the academic year of 2014-2015. All of the students were chosen from two sections of each of four different grades of 9th, 10th, 11th, and 12th. All the students in research group were male adolescents in between the ages of 15-18. The demographic features of participants are shown in Table 1. The proficiency level of the students is significant for the analysis of the positive and negative metaphors.

Two different focus group interviews were held with seven students having negative and positive perspectives to determine the effect of the perceptions on students' motivation in learning English. So, the participants of the focus group interview were determined according to the results of the metaphor technique. This stage is the second stage of the research. The participant were 4 students having the even numbers in the group of students who construct positive metaphors and 3 students having the odd numbers in the sequence of students who construct negative metaphors in the first stage. The participants' details are given in Table 1. 
Table 1. Distribution of Students' Demographic Information

\begin{tabular}{|c|c|c|c|}
\hline & & $\mathrm{n}$ & $\%$ \\
\hline \multirow[t]{3}{*}{ Age } & $15-16$ & 62 & 48,4 \\
\hline & $17-18$ & 66 & 51,6 \\
\hline & TOTAL & 128 & 100,0 \\
\hline \multirow[t]{5}{*}{ Grade } & 9th & 23 & 18,0 \\
\hline & 10th & 34 & 26,6 \\
\hline & 11th & 40 & 31,3 \\
\hline & 12th & 31 & 24,2 \\
\hline & TOTAL & 128 & 100,0 \\
\hline \multirow[t]{4}{*}{ Socio-economic Level } & Low & 27 & 21,1 \\
\hline & Middle & 86 & 67,2 \\
\hline & Upper & 15 & 11.7 \\
\hline & TOTAL & 128 & 100,0 \\
\hline \multirow[t]{3}{*}{ Type of Secondary School } & State & 107 & 83,6 \\
\hline & Private & 21 & 16,4 \\
\hline & TOTAL & 128 & 100,0 \\
\hline \multirow[t]{6}{*}{ Region } & Western & 55 & 43,0 \\
\hline & $\begin{array}{c}\text { (Marmara, Aegean, } \\
\text { Mediterranean) }\end{array}$ & & \\
\hline & Black Sea & 19 & 14,8 \\
\hline & Central Anatolia & 25 & 19,5 \\
\hline & Eastern Anatolia & 29 & 22,7 \\
\hline & TOTAL & 128 & 100,0 \\
\hline \multirow{5}{*}{$\begin{array}{c}\text { Proficiency Level in } \\
\text { English }\end{array}$} & Beginner-Elementary $(0-45)$ & 25 & 19,5 \\
\hline & Low Intermediate (45-65) & 37 & 28,9 \\
\hline & High Intermediate $(65-85)$ & 45 & 35,2 \\
\hline & Advanced $(85-100)$ & 21 & 16,4 \\
\hline & TOTAL & 128 & 100,0 \\
\hline
\end{tabular}

\subsection{Limitations of the Study}

The state school where this study was carried out is a special technical school having private rules and regulations about data privacy. Working as an instructor of English at this state high school, the researchers have to obey these limitations on data privacy. That's why, the name of the school and of the participants in the interviews are not stated openly but coded such as NS1 (Student having negative perception 1) or PS4 (Student having positive perception 4). In addition, instead of conducting the study upon all students in the high school, the researchers preferred to collect the metaphoric data only from two classes in each grade. It means the researcher working at this school knows the students better and have a constant contact with them. This gives her the chance to collect the data easily.

\subsection{Data Collection Procedure}

This study is based on two different qualitative research stages: metaphor technique and focus group interview. The first stage was conducted via a two-question questionnaire form on which the students were expected to construct mental images about the concepts "The English" and "English Culture" as in "The English" is like ...because... and "English Culture" is like ... because...

Before handing out the forms to students, they were provided with a very detailed explanation on what a metaphor is and how and why it is constructed by giving a variety of examples from different subject areas. When the data from first 52 students were collected, it was noticed that 18 of the students gave the sheets empty whereas 32 of them did not answer the first question on the concept "The English" but tried to develop metaphors on "English Culture". When they were asked for the reason, they declared that they had hard time to construct a mental image about the English people. Of 32 students who ignored the concept "The English" but focused on "English Culture", 24 students perceived the concept "English Culture" as "English" as a broader term and constructed images such as "a difficult lesson", "a widespread foreign language" rather than as "a culture belongs to the English". Moreover, 13 of these 24 students literally crossed out the word "culture" or underlined or circled only the word "English" and produced their metaphors on it. There were only 2 students who could construct relevant metaphors on both concepts as English society and culture. This did not provide adequate meaningful data for the research. After observing this tendency in students to ignore the concept "The English" and to produce metaphors on the broader concept "English" rather than "English Culture", the forms were revised and they were asked to construct mental images only on the concept "English".

Finally, the study was conducted with 128 students via a sheet of paper with the prompt "English" is like...because... The teaching researcher also explained what a metaphor is by giving some examples in order to clarify what they were exactly supposed to do. Then, she answered all the questions arouse in the class in order to avoid any possible misunderstandings by constructing further examples of metaphors on various concepts. Furthermore, the students were asked to focus on the metaphors they produced and clarify their reasons. The students were also allowed to write either in English or in Turkish in order to feel free and express themselves easily and accurately. This time, the teaching researcher additionally declared that while constructing metaphors, they could write down the first image that first appears in their mind when they see or hear the word "English". It obviously made the whole process so clear and easy 
for the students that they not only constructed more relevant metaphors but also stated more meaningful reasons for their choices by filling the blanks in the given prompt. Saban (2004:31) puts forward the idea that the phrase "is like" is used to associate more clearly the link between the topic and the vehicle of the metaphor in research studies where metaphors are used as qualitative research instrument. With the explanatory conjunction "because", the students created sense reasons why they constructed these metaphors which help to identify the key words and form conceptual categories accordingly.

In the second stage, two different focus group interviews are held with seven students to determine the effect of perceptions on students' motivation in learning English. Seven students were chosen as the representatives of the students having negative and positive images. In the first focus group interview, there were 4 students having constructed positive metaphors. These were the students with even numbers (Student 2, Student 4, Student 6, and Student 8) in the sequence of nine-student group having constructed repeated positive dialogs in the first stage. For the second interview, 3 students having the odd numbers were chosen (Student 1, Student 3, and Student 5) from the sequence of six-student group having constructed repeated negative metaphors. During both interviews, the meeting room was quiet, physically comfortable, and free from any outsider distraction not to avoid the respondents from focusing on the discussion. The aim was to create a relaxed, informal atmosphere where the participants felt free to express their personal opinions openly and sincerely. The interviewer did not express any personal comments and made no judgments on the opinions of the participants for impartiality. All participants were led to participate equally so that one participant should not be allowed to dominate the discussion. Both sessions were tape recorded and transcribed after the meeting. All the participants checked the texts in turns after the discussion for validity and reliability.

\subsection{Data Analysis}

\subsubsection{Coding}

At first, all the data collected from the metaphors, produced by 128 students participated in the study was listed in alphabetical order in order to code them easily. In coding process, only one sheet of paper on which the student wrote a general sentence on learning English as "we forget it when we don't study" instead of a proper metaphor was excluded from the scope of data analysis and was not coded. In this step, the prompts, filled in Turkish were all translated in English whereas the ones written in English were taken as original into analysis. After listing, coding, and excluding the irrelevant data, seventy nine relevant metaphors were collected. Thus, a sample list of metaphors was prepared to compile students' metaphorical images. The list of metaphors (given in Table 2) not only helped the researchers in grouping the metaphors under certain categories but also validated data analysis process and interpretations of the research, as well. In this stage, 79 relevant metaphors were produced and 24 metaphors were commonly shared by two or more students whereas 55 metaphors were constructed by only one student.

\subsubsection{Categorizing}

When it came to developing conceptual categories out of 79 metaphors, the participants' metaphors of "English" were analyzed in terms of their common features. In other words, how the participants conceptualized the metaphors was analyzed. Each metaphor image was analyzed in terms of the metaphor topic "English", the metaphor vehicle and the ground which means the relationship between the topic and the vehicle. Later, each metaphor was associated with a certain theme. As a result of this review and analysis, 12 different conceptual categories were formed and they were determined and stated in tables in the section of findings. In the further steps, the single metaphors constructed by only one student were not taken into consideration in data analysis, and three categories which merely consisted of single metaphors were omitted. Therefore, the analysis was carried on within 9 different conceptual categories which also consisted of repeated metaphors.

\subsubsection{Validity and Reliability}

In order to establish the validity and reliability of the research, basically, the researchers clearly explained the whole data analysis process in details ranging from the decision on data collection instruments, collecting meaningful data via these instruments to the coding and categorizing the raw data into common categories step by step in details. The researchers also compiled a detailed list of metaphors to represent each of 79 metaphors. Furthermore, external expert opinion and peer-review are employed to confirm whether metaphors listed under 12 common conceptual categories represented all metaphors accurately or not. After determining 79 metaphors and developing 12 common conceptual categories, the researchers transferred all data to SPSS package program for quantitative data analysis basically to calculate the number (f) and percentage (\%) of participants that represented 40 metaphors and 8 categories presented in Table 2. This very basic SPSS analysis contributed a quantitative dimension to the qualitative research and very much helped to improve validity and reliability of it as well. In addition to the analysis of data collected via metaphors, two different focus group interviews were held with 7 students to determine the effect of perceptions on students' motivation in learning English. 4 students having the even numbers in the group of students who constructed positive 
metaphors and 3 students having the odd numbers in the sequence of students who constructed negative metaphors were chosen to participate in two different focus group interviews. Both of the focus group interviews were recorded on tape, carefully listened and transcribed by the researchers. The names of the participants on the tape recording were omitted and coded such as NS1 (Student having negative perception 1) or PS4 (Student having positive perception 4). All the participants checked the transcribed texts in turns after the discussion. Then, the researchers scanned the transcript to locate the reoccurrences of the key words and concepts. The key word list was also checked and peer-reviewed by two colleagues working in the same department with the researchers in order to maintain the reality and validity. In the analysis, these key concepts were grouped and interpreted in some main categories from which the following findings were generated and the central themes of discussion were derived.

\section{Findings and Discussion}

Within this main purpose of this study is to find out (a) what metaphors high school students construct about the concept of "English" and (b) how students' negative and positive perceptions of "English" affect their participation and motivation in learning English. So, on the first stage, the researchers conducted the metaphor study and, in the second stage, they conducted the focus group interviews to collect the data.

\subsection{What Metaphors High School Students Construct about the Concept of "English"}

The metaphors constructed by the students about the concept "English" are given below (in Table 2) with the number and percentage of students representing each metaphor. 
Table 2. Metaphors on "English" and the Number and Percentage of Students

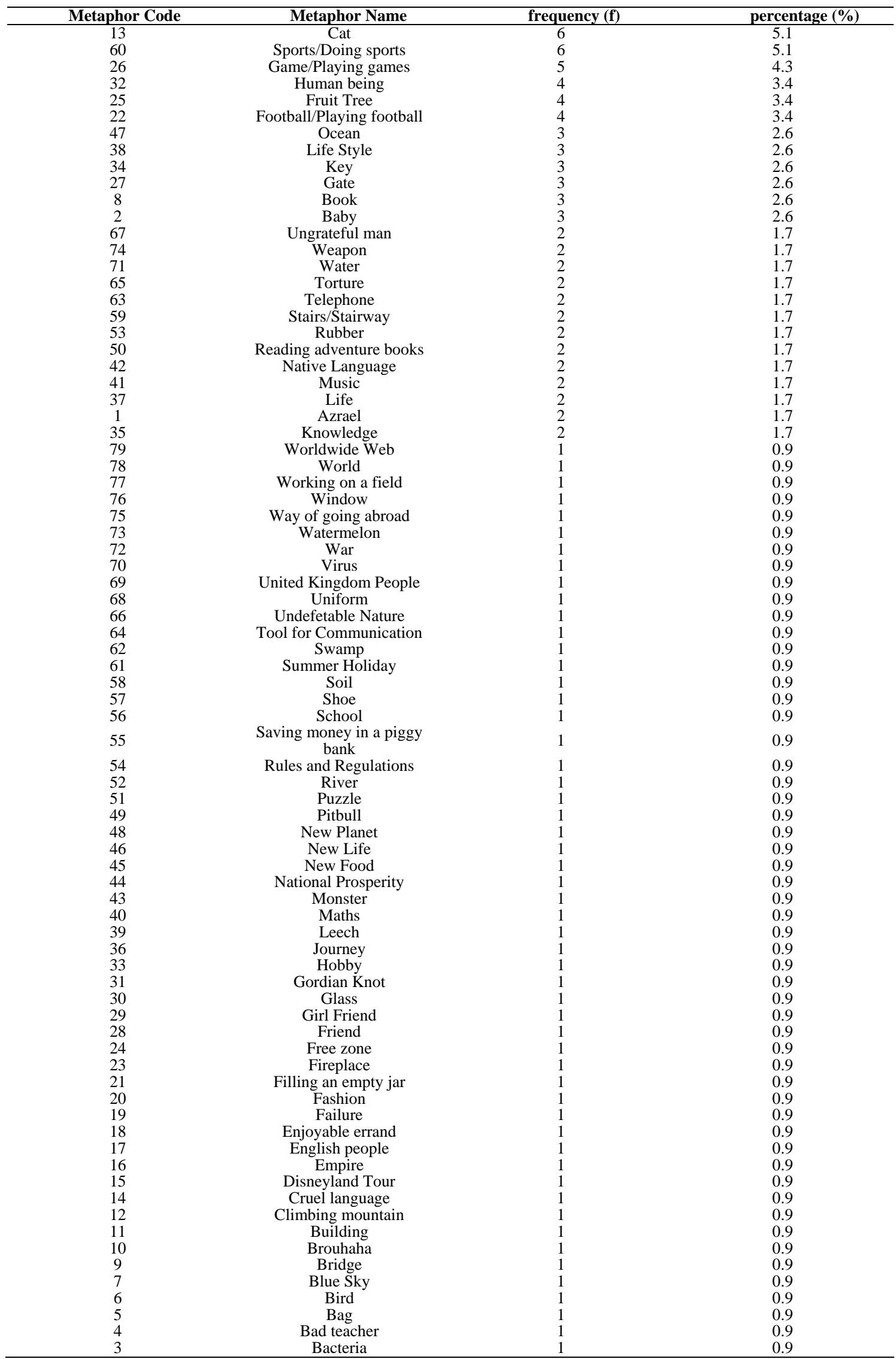

- $\quad$ The students produced 79 relevant metaphors about "English". 
- 54 of these 79 metaphors are represented only one student whereas 25 of them are represented by two or more students.

- The metaphors listed in the first five counts are as follows: 1. cat (6 students, 5.1\%), 2. sports/doing sports (6 students, 5.1\%), 3. game/playing games (5 students, 4.3\%), 4. football/playing football (4 students, $3.4 \%$ ), 5 . human being (4 students, 3.4\%).

- 46 of the metaphors constructed by the students can be associated with nonliving things such as, key, rubber, books, weapon, telephone, window, uniform, shoe, glass and building whereas twenty three of the metaphors can be associated with living things such as cat, human being, fruit tree, watermelon, baby, virus, bacteria, soil, and leech.

- 35 of the metaphors associated with abstract concepts are listed as space, life style, fashion, music, Azrael, monster, journey, Disneyland tour, national prosperity, native language, hobby, brouhaha, and failure whereas in 22 of the metaphors the students express their perceptions with actions such as reading adventure books, playing football, playing games, climbing a mountain, filling in an empty jar, working on a field, and saving money in a piggy bank.

\subsubsection{The Categories}

The metaphors provided by the participants were grouped under 12 categories listed in terms of frequency and percentage. In parallel with these categories, logical explanations and reasons suggested by the students in the "because...." clause of the given prompt were stated and analyzed. The metaphors were grouped under following categories according to their common feature. Under each category, one example is given for each of the metaphors with their actual explanation. In addition, each prompt is followed by the grade and the current proficiency point of students in parentheses.

\subsubsection{English as a Process Requiring Time, Effort and Patience}

There are 12 relevant metaphors, constructed by 28 students in this category. Of these metaphors, 5 metaphors are repeated whereas 7 metaphors are constructed by only one student and eliminated from the study. They are listed as sports/doing sports, fruit tree, football/playing football, human being, baby, school, virus, filling an empty jar, working on a field, saving money in a piggy bank, survival in a swamp and climbing a mountain. In this category, some of the students constructing the metaphors of "sports" and "football" prefer to use them in action form such as "doing sports" or "playing football" but mean the same concept. Sports/Doing sports (6 students, 5.1\%) is the most significant item of this category. When the reasons for the metaphors are analyzed, it is seen that the common standpoint that English is a language that should be/is taught and learned in a gradually developing process that requires a hard work, effort, a definite time and patience.

Table 3. Data Regarding the Category of English as a Process Requiring Time, Effort and Patience

\begin{tabular}{cll}
\hline & $\mathbf{n}$ & \% \\
\hline Sports/Doing sports & 6 & 5.1 \\
Fruit Tree & 4 & 3.4 \\
Football/Playing football & 4 & 3.4 \\
Human being & 4 & 3.4 \\
Baby & 3 & 2.6 \\
School & 1 & 0.9 \\
Virus & 1 & 0.9 \\
Filling an empty jar & 1 & 0.9 \\
Working on a field & 1 & 0.9 \\
Saving money in a piggy bank & 1 & 0.9 \\
Swamp & 1 & 0.9 \\
Climbing mountain & 1 & 0.9
\end{tabular}

The students explain the logical reasons for their choice of metaphor by using following statements:

English is like doing sports because your level is bad at the beginning, but it progresses as you exercise (11th grade 62)

English is like playing football because the harder you practice, the sooner you improve your level. (10th grade - 65)

English is a fruit tree because when you provide its necessities and fulfill its requirements; it will be always in a progress and give you various fruits as a reward in return of your care and hard work. (11th grade - 60)

English is like a human being because as he receives care and education, he improves and becomes mature. (10th grade - 65)

English is like a baby because you first start learning English in beginner and elementary level as a baby who starts 
walking for the first time. Then, you run marathon as you become advanced in English. (11th grade - 89)

English like a school because English is one of the most important lessons learned at school. (11th grade - 52)

English is like a virus because once it starts spreading, once you stop studying, you can never avoid failure. (9th grade - 62)

English is like filling an empty jar because how much you fill it, it will be this much full as studying for and achieving English exams. (10th grade - 75)

English is like working on a field because if we work on a field patiently, we can harvest abundant and qualified crops. If we study English regularly, we can achieve it. (12th grade - 73)

English is like saving money in a piggy bank because when you put money aside in a piggy bank, you cannot know how much you save till you break it open. Just like it, when you study English, maybe you cannot notice how much you progress but if you do not quit but go on studying, you can see how much your English gets improved. (10th grade - 76)

English is like a swamp because you can succeed only if you constantly step forward cautiously and patiently. But if you move impatiently or stop even for a while, you cannot keep your head above, you start loosing your level even drowning.(12th grade - 92)

English is like learning English is as hard as climbing Everest but once you achieve it, and reach the summit, it is priceless. (12th grade - 56)

\subsubsection{English as Joy or Fun}

14 students in total construct 8 different metaphors classified in the conceptual category of "English as Joy and Fun". There are 3 metaphors which are repeatedly constructed whereas 5 metaphors are constructed by only one student and omitted from data analysis. The metaphors are listed as game/playing game, music, reading adventure books, summer holiday, hobby, bird, enjoyable errand and Disneyland tour. The most significant metaphor is the metaphor of "Game/Playing games" which is mostly constructed by the students (5 students, 4.3\%). The common reason drawn from students' explanations of their metaphors can be stated as studying English is an enjoyable activity as it always provides you new ways to express yourself and feel relaxed and happy. The metaphors reflect positive perceptions of the students whose proficiency level are all above 75, except one. It can be said that successful students having no problem with understanding and using English generally have positive perceptions about the term "English".

Table 4. Data Regarding the Category of English as Joy or Fun

\begin{tabular}{llc}
\hline & $\mathbf{n}$ & \% \\
\hline Game/Playing game & 5 & 4.3 \\
Music & 2 & 1.7 \\
Reading adventure book & 2 & 1.7 \\
Summer Holiday & 1 & 0.9 \\
Hobby & 1 & 0.9 \\
Bird & 1 & 0.9 \\
Enjoyable errand & 1 & 0.9 \\
Disneyland Tour & 1 & 0.9 \\
\hline
\end{tabular}

In this category, the students also explain the logical reasons for their choice of metaphor by using following statements:

English is like playing game because I enjoy studying and speaking English. (12th grade - 87)

English is like music because it is a language that everyone knows and everyone can connect with each other and be happy. (11th grade - 85)

English is like reading a new adventure book because studying English always brings me big and sudden changes makes me excited and provides me new knowledge. (11th grade - 78)

English is like summer holiday because as we study we have fun, and we can get in touch with tourists via language that make us have enjoyable time in summer holiday. (10th grade - 85)

English is like a hobby because when I practice English, I feel unique and happy. (12th grade - 91)

English is like a bird because it is a vast and free language that exists all around the world just like free and happy birds. (11th grade - 65)

English is like an enjoyable errand because it is easy and enjoyable to learn. When I speak in English I want to speak more. It makes me feel better. (10th grade - 86)

English is like a Disneyland tour because if you are very much concerned about the rules of the tour, you cannot get any pleasure from, you can miss the real joy of it.(12th grade -92) 


\subsubsection{English as a Tool for/Way of Achieving a Goal}

There are 13 relevant metaphors, constructed by 19 students in total in the category of "English as a Tool for/Way of Achieving a Goal". 4 metaphors are repeatedly constructed whereas 9 metaphors are single metaphors constructed by only one student, and eliminated from the scope of analysis. They are listed as key, gate, weapon, knowledge, glass, bag, blue sky, uniform, soil, free zone, window, way of going abroad, and bridge. Key and gate (3 students, $2.6 \%$ ) is the most significant items, repeated the most in this category. When the explanations the students make for their metaphors are analyzed, it can be said that English is a language that is used as an instrument in achieving a goal. Of all the goals stated by the students, communicating with people all around the world is the most significant one. Expressing oneself, going abroad, performing one's profession, and making profit are among the things that can be done by using English language as a tool, too.

Table 5. Data Regarding the Category of English as a Tool for/Way of Achieving a Goal

\begin{tabular}{llc}
\hline & $\mathbf{n}$ & $\%$ \\
\hline Key & 3 & 2.6 \\
Gate & 3 & 2.6 \\
Weapon & 2 & 1.7 \\
Knowledge & 2 & 1.7 \\
Glass & 1 & 0.9 \\
Bag & 1 & 0.9 \\
Blue Sky & 1 & 0.9 \\
Uniform & 1 & 0.9 \\
Soil & 1 & 0.9 \\
Free zone & 1 & 0.9 \\
Window & 1 & 0.9 \\
Way of going abroad & 1 & 0.9 \\
Bridge & 1 & 0.9 \\
\hline
\end{tabular}

Examples of the metaphors and their explanations listed in this category are as follows:

English is like a big key because if every nation, culture and human is a different door, English is the key to all these doors. As a common language spoken all over the world, it enables people understand each other. (11th grade - 93)

English is like a gate to whole world it enables people all around the world to communicate and understand each other. (12th grade - 90)

English is like an effective weapon because we will use it against our counterparts when the time comes. (11th grade 76)

English is like knowledge because no matter what you search for, you can find most resources in English. (11th grade 79)

English is like a glass because it enables us to see the things much more clearly. (11th grade -90)

English is like a bag that I will always carry and use in my professional life because I will use this language to represent my country in international arena in the best way. (12th grade -95)

English is like blue sky for me because I want to be a pilot, and use my English. (9th grade - 39)

English is like a uniform because we cannot perform our job without English as a soldier cannot do without his uniform. (10th grade - 64)

English is like soil because everyone on earth has a chance to use it and make profit. (11th grade - 60)

English is like a free zone which makes everyone free and relaxed to explain anything. (11th grade - 71)

English is like a window because you can see the good side through it. (11th grade -52)

English is like a way of going abroad because without English I cannot go abroad. (11th grade - 70)

English is like a bridge because it is my link abroad. (11th grade - 79)

\subsubsection{English as a Constantly Changing Entity}

In the category of "English as a Constantly Changing Entity", 10 students in total focus on the ever changing nature of English language in the explanations of their metaphors. There are 6 relevant metaphors constructed and classified into this category, the most repeated one of which is "book" (3 students, $2.6 \%$ ). In this category, 3 metaphors are repeatedly constructed whereas three metaphors are constructed by only one student, and eliminated from the scope of analysis. The metaphors are listed as book, life, rubber, journey, building, and shoe. The common points are that English has a varied and constantly changing nature, it provides the learner with different and varied forms of knowledge in each level, and it is spoken by various kinds of people all around the world. 
Table 6. Data Regarding the Category of English as a Constantly Changing Entity

\begin{tabular}{lcc}
\hline & n & \% \\
\hline Book & 3 & 2.6 \\
Life & 2 & 1.7 \\
Rubber & 2 & 1.7 \\
Journey & 1 & 0.9 \\
Building & 1 & 0.9 \\
Shoe & 1 & 0.9 \\
\hline
\end{tabular}

The metaphors are exemplified in order as follows:

English is like a book because it varies like books such as adventure, psychology etc. Each time you read it, it multiplies and you can elicit new meanings. (10th grade - 59)

English is like life because it is the language of whole world and various cultures. (11th grade - 55)

English is like rubber because as you stretch it, it lengthens. As you study English harder, it improves. But once you quit it, it shortens gets worse. (11th grade - 56)

English is like a journey because in every different place you visit, you learn different things. In every level of English, you learn various words and idioms. (12th grade - 77)

English is like a building which is very simple and dull outside but colorful and magnificent inside because English does not affect the learner outside, but as the learner gets inside, it reveals all the good sides in it. (12th grade - 86)

English is like a pair of shoes because as you wear it, it gets a different shape, as you study English, you change and improve. (9th grade - 57)

\subsubsection{English as a Two-sided Concept}

15 students in total constructed 8 relevant metaphors that can be grouped under the category of "English as a Two-Sided Concept". In this category, 2 metaphors are repeatedly constructed whereas 6 metaphors are single metaphors constructed by only one student, and ignored in data analysis. "Cat" is the most repeated metaphor of all categories (6 students, 5.1\%). In this category, cat is followed by the other metaphors which are listed as water, bacteria, friend, fireplace, watermelon, empire, and maths. English is mostly resembled to a cat, which can be a good natured pet when treated gently and cared well but turn to be an ungrateful animal that can harm you when neglect it. Just like a cat, learning English is a two-sided concept which can be improved by regular study, but can get worse once you neglect practicing. It can be said that the students' metaphors in this category all indicate the common idea that English language learning has two contrasting sides depending on students care, interest, and effort.

Table 7. Data Regarding the Category of English as a Two-Sided Concept

\begin{tabular}{lcc}
\hline & n & \% \\
\hline Cat & 6 & 5.1 \\
Water & 2 & 1.7 \\
Bacteria & 1 & 0.9 \\
Friend & 1 & 0.9 \\
Fireplace & 1 & 0.9 \\
Watermelon & 1 & 0.9 \\
Empire & 1 & 0.9 \\
Maths & 1 & 0.9 \\
\hline
\end{tabular}

Examples of the metaphors and their explanations listed in this category are as follows:

English is like a cat because it makes a great pet if you take good care of it but it can be so ungrateful that you can easily forget everything if you don't study. (11th grade - 58)

English is like water for me because the water making us live today can make us drown tomorrow. today English which is very beneficial for us can cause us to be assimilated in the future. (12th grade -68)

English is like a bacteria because it can make you sick when used as a tool for culture assimilation or it can make you healthier when used for good aims. (12th grade - 86)

English is like a friend because when you spare your time for him, you can build a good friendship but if you ignore him, you can lose him.

English is a fireplace because as you come closer you can get warmer, as you go farer you can get cold. (10th grade75)

English is like a watermelon because it is hard outside but soft, juicy, and tasteful inside. (12th grade - 70)

English is like an empire because if the empire will develop you win, if empire will lost you are dead. (9th grade - 70)

English is like Maths because it requires hard work and caution but once you get it, it becomes easy and enjoyable. (9th grade - 50) 


\subsubsection{English as an Endless-infinite Entity}

There are 5 relevant metaphors constructed by 8 students in the category of "English as an Endless and Infinite Entity". In this category, 2 metaphors were repeatedly constructed whereas 3 metaphors were constructed by only one student, and ignored in data analysis. The metaphors are ocean, stairs, puzzle, world, and river. Ocean (3 students, $2.6 \%)$ is the most commonly constructed metaphor in this category. According to the analysis of the metaphors, the common stand point that English includes a huge amount of new knowledge for the new learners which varies in each level of learning.

Table 8. Data Regarding the Category of English as an Endless Infinite Entity

\begin{tabular}{lll}
\hline & n & \% \\
\hline Ocean & 3 & 2.6 \\
Stairs/Stairway & 2 & 1.7 \\
Puzzle & 1 & 0.9 \\
World & 1 & 0.9 \\
River & 1 & 0.9 \\
\hline
\end{tabular}

Below is given examples of the metaphors included in this category:

English is like an ocean because it is an never ending world that no matter how much you study there is still to many new things to learn and to explore deep inside. (10th grade - 60)

English is like a puzzle because no matter how much you learn, there is still too much to learn. (9th grade - 34)

English is like the world because there are lots of knowledge in English, you will never know all. (11th grade - 60)

English is an endless river because it takes you inside and you flow to infinity with it. (10th grade - 90)

\subsubsection{English as a New Concept}

There are 3 relevant metaphors conceptualized by 3 students under the category of "English as a New Concept". In this category, English is perceived as a new body of words, phrases, grammatical structures and linguistic rules according to the non-native students learning it as a foreign language. They are listed as new food, new life, and new planet all of which are all single metaphors constructed by only one student (1 student, $0.9 \%)$. That's why, this category and the metaphors were entirely ignored and not taken into any further analysis.

Table 9. Data Regarding the Category of English as a New Concept

\begin{tabular}{lcc}
\hline English as a New Concept & n & \% \\
\hline New Food & 1 & 0.9 \\
New Life & 1 & 0.9 \\
New Planet & 1 & 0.9 \\
\hline
\end{tabular}

Three statements below are chosen as examples of the metaphors constructed under this category:

English is like a new food because it is a new taste that I've never had before. (10th grade - 77)

English is like a new life because it maintains a new livable life that is opening new aspects of it. (11th grade - 81)

English is a new planet because English is a new and different world, planet, and atmosphere. (12th grade - 71)

\subsubsection{English as Fear and Hatred}

16 students in total construct 13 metaphors grouped under the category as "English as Fear and Hatred". In this category, 3 metaphors were repeatedly constructed whereas 10 metaphors were constructed by only one student, and ignored in data analysis. Azrael, torture and ungrateful man (2 students, $1.7 \%$ ) are the most commonly shared metaphors followed by the single ones; pitbull, war, monster, undefinable nature, brouhaha, gordian knot, darling, failure, bad teacher, and cruel language (1 student, 1.7\%). The metaphors reflect negative perceptions of the students whose proficiency level are all below 50, except one. It can be said that students repeatedly facing failure in English lessons and having constant hardship in learning and succeeding English perceive the concept of "English" in a negative way.

Table 10. Data Regarding the Category of English as Fear and Hatred

\begin{tabular}{lll}
\hline & n & \% \\
\hline Azrael & 2 & 1.7 \\
Torture & 2 & 1.7 \\
Ungrateful man & 2 & 0.9 \\
Pitbull & 1 & 0.9 \\
War & 1 & 0.9 \\
Monster & 1 & 0.9 \\
Undefeatable Nature & 1 & 0.9 \\
Brouhaha & 1 & 0.9 \\
Gordian Knot & 1 & 0.9 \\
Darling & 1 & 0.9 \\
Failure & 1 & 0.9 \\
Bad teacher & 1 & 0.9 \\
Cruel language & 1 & 0.9 \\
\hline
\end{tabular}


The negative metaphors listed in Table 10 are exemplified as follows:

English is like Azrael because in every English exam I am in mortal fear and I feel like drowning. (10th grade - 42)

English is like a torture because it becomes so boring because of wrong teaching methods. (9th grade - 54)

English is like an ungrateful man because if you ignore it for a while, it forgets you. (10th grade - 50)

English is like a pitbull because it causes hatred in me whenever I see or hear it. (12th grade - 34)

English is like a war because in a war once enemies break your line, you are dead. In English if you don't like it, you never learn it. (11th grade - 38)

English is like a monster because it bites and eats me, I never take any good grade no matter how hard I try. (9th grade - 46)

English is like undefeatable nature because it is a very difficult language to learn, no matter how hard I study, I cannot achieve it. (9th grade - 32)

English is like brouhaha it is very complicated and difficult to understand what I hear and understand the new words. (11th grade - 71)

English is like a gordian knot because it requires time; it can never be figured out and unbound at once. (11th grade 56)

English is like a darling because when you start a relationship it leaves you. (9th grade - 45)

English is like failure because I am always unsuccessful in English. (11th grade - 46)

English is like a bad teacher because I have unpleasant memories. (11th grade - 37)

English is like a cruel and unfair language because this is all I see in English lessons. (10th grade - 50)

3.1.1.9 English as a Communication Tool

In this conceptual category, there are 4 relevant metaphors, 2 of which are commonly shared by 2 students whereas the other two were constructed by only one student. The metaphors constructed by 6 students in total are listed as native language (Student 2, 1.7\%), telephone, tool for communication, and worldwide web. The common stand point of these four metaphors is that the most significant function of English as a language is communication among people around the world.

Table 11. Data Regarding the Category of English as Communication

\begin{tabular}{lll}
\hline & n & \% \\
\hline Native Language & 2 & 1.7 \\
Telephone & 2 & 1.7 \\
Tool for Communication & 1 & 0.9 \\
Worldwide Web & 1 & 0.9 \\
\hline
\end{tabular}

The explanations for the metaphors conceptualized under this category are given below:

English is like my native language because I don't think when I hear something in English, I directly understand it and easily use it to communicate. (11th grade - 64)

English is like a telephone because it helps me get in touch with the places and people I want. (11th grade - 70)

English is like a tool for communication because we can speak to most of the world by using it. (11th grade - 74)

English is like worldwide web (www) because if you can speak English, you can communicate with all world. (11th grade - 64)

\subsubsection{English as a Way of Living}

5 students in total perceive "English" as a way of living and constructed the metaphors of life style (3 students, 2.6\%), fashion, and rules and regulations. In this category, one of the metaphors was repeatedly constructed whereas 2 metaphors were constructed by only one student, and eliminated from data analysis.

Table 12. Data Regarding the Category of English as a Way of Living

\begin{tabular}{lcc}
\hline & $\mathbf{n}$ & \% \\
\hline Life Style & 3 & 2.6 \\
Fashion & 1 & 0.9 \\
Rules and Regulations & 1 & 0.9 \\
\hline
\end{tabular}

The students state the logical reasons for their metaphors as follows:

English is like a life style because we use English everywhere and all the time in our daily life. (10th grade - 85)

English is like fashion, a style because to use English in my daily life makes me feels cool. (10th grade - 55) 
English is like rules and regulations because we use English in every aspect of life and accept it as a living style. (10th grade - 56)

\subsubsection{English as a Society}

In the conceptual category, there are only 2 metaphors which are single metaphors constructed by only one student, and thus omitted from the scope of data analysis. This category was not taken into further analysis for the same reason, either. In this category, the metaphors show that students conceive "English" as a definite group of people belonging to a nation and culture.

Table 13. Data Regarding the Category of English as a Society

\begin{tabular}{lll}
\hline & $\mathbf{n}$ & \% \\
\hline English People & 1 & 0.9 \\
United Kingdom Culture & 1 & 0.9 \\
\hline
\end{tabular}

Examples of the metaphors and their explanations listed in this category are as follows:

English is like cold and formal English people because it always reminds me of the life style of people living in England. (12th grade - 86)

English is like United Kingdom culture because the first thing that comes to my mind when I hear the word English is the accent of British people that I have always loved since my childhood. (10th grade - 92)

\subsubsection{English as a Political Issue}

The last group of metaphors is "English as a Political Issue", which is also ignored in data analysis because it consists of only two single metaphors, which are listed as national prosperity and leech, constructed by only one student. According to their explanations given below Table 14, these two students perceive "English" as a political issue. One of them perceives teaching one country's own language to foreign people as a national success whereas the other one conceptualizes learning English as being assimilated.

Table 14. Data Regarding the Category of English as a Political Issue

\begin{tabular}{lll}
\hline & n & \% \\
\hline National Prosperity & 1 & 0.9 \\
Leech & 1 & 0.9 \\
\hline
\end{tabular}

The students explain the logical reasons for their metaphors by using following statements:

English is like a national prosperity because it is the capability to make foreign people belonging to a different language, religion and culture your own language. (12th grade - 68)

English is like a leech because it assimilates people and sucks their blood as England's having colonized dozens of countries. (12th grade - 91)

According to the data collected by the metaphor study, most of the students (28 students) construct metaphors that are grouped under the category of "English as a Process Requiring Time, Effort and Patience" whereas only 2 students percept "English" as a society or political issue. In other words, students tend to perceive "English" as a gradual process of learning a language in which they should always take their time studying regularly, cautiously, and patiently rather than a language spoken by a definite nation or a political issue.

After the elimination of 54 single metaphors, constructed by only one student, 25 repeated metaphors constructed by 73 students in total were left. In parallel, after omitting the conceptual categories of "English as a New Concept", "English as a Society" and "English as a Political Issue"t (as hey merely consist of single metaphors) the research was conducted within 9 conceptual categories. The graphic below demonstrates the distribution of metaphors within nine conceptual categories in percentages.

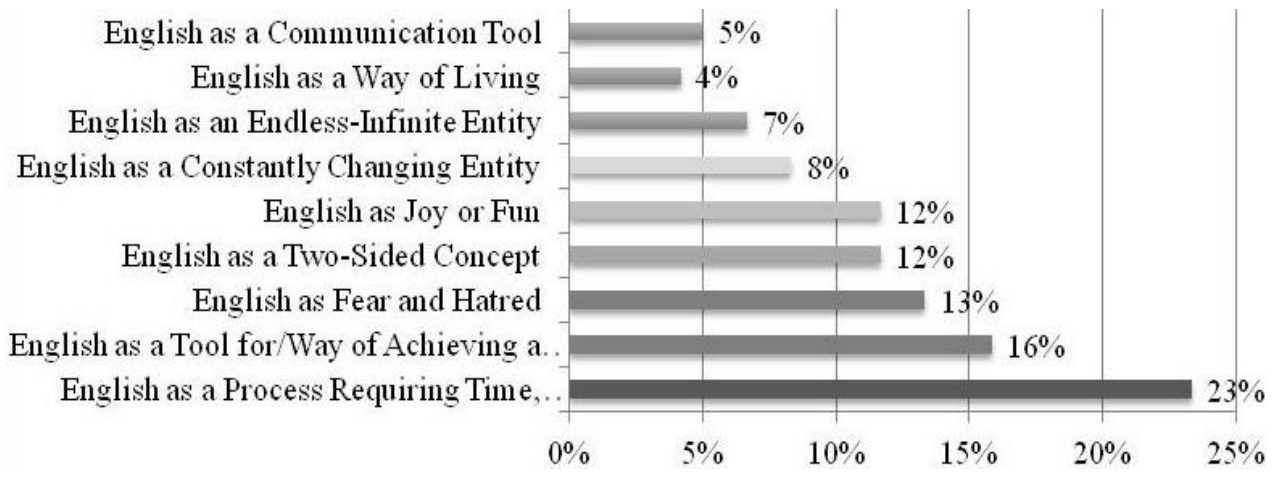

Graphic 1. Distribution of Metaphoric Conceptual Categories 


\subsection{How Students' Negative and Positive Perceptions of "English" Affect Their Participation and Motivation in Learning English.}

\subsubsection{Focus Group Interview}

In order to find out how students' negative and positive perceptions of "English" affect their participation and motivation in learning English, the focal point is on the categories of "English as Joy or Fun" and "England as Fear and Hatred" representing the positive and negative perception of students on "English". 14 students in total constructed 8 different metaphors classified in the conceptual category of "English as Joy and Fun" whereas 16 students in total constructed 13 metaphors grouped under the category as "English as Fear and Hatred". According to this set of data, it can be said that there are obviously more students who construct negative metaphors and there are more relevant negative metaphors in comparison to the positive ones.

There are 9 repeated positive metaphors, listed as game/playing game, music, reading adventure books after 5 single positive metaphors (summer holiday, hobby, bird, enjoyable errand, Disneyland tour) are omitted. In parallel, there are 6 repeatedly constructed negative metaphors, listed as Azrael, torture, and ungrateful man after 10 single negative metaphors (pitbull, war, monster, undefinable nature, brouhaha, gordian knot, darling, failure, bad teacher, cruel language) are eliminated.

To determine the effect of students' negative and positive perceptions of "English" on their participation and motivation in learning English, the researchers conducted two focus group interviews with 7 students having positive and negative views. The first interview was with nine students having positive images in order and they had numbers from 1 to 9 . Then, the students with even numbers $(2,4,6,8)$ were covered and four students participated in the first focus group interview. Moreover, the same step was employed for the second interview. 6 students having negative images were taken in order and they were numbered from 1 to 6 . Likewise, the students with odd numbers $(1,3,5)$ were selected and thus 3 students took part in second focus group interview.

In the first group, the interview was with four students having positive views on "English". The first student with positive perception on "English", coded as PS1, is a 12th grade student who has quite a high score in English (OPT:92). He says: "English is like an enjoyable game for me, I get a great pleasure in English lessons" when asked the reason for the metaphor of "game". He adds that while trying to comprehend a written passage or understand a listening passage by taking notes, he feels like figuring out an enjoyable puzzle. All the students share the common idea that they never hesitate to participate in any activity in class as they think to participate in class is students' mere chance to practice and improve their English.

The second student having positive perception, PS2, also resembles "English" to "playing games" and he is a 12th grade student having a high score in English (OPT:87). He explains the reason why he constructs this metaphor as "Being able to express myself in English makes me feel relaxed and happy just like I am playing a very pleasurable game". He also says that he always looks forward to having any chance to speak to Philip who is a native speaker, also an instructor of English in English lessons. All of the students agree that a student can only learn English when he or she feels like playing a game and forgets the fact that he is in a lesson, trying hard to learn English.

Third student having positive perception, PS3, is a 11th grade student having high intermediate level in English (OPT:76). He constructed the metaphor of "music" and explains his choice as follows: "English is like music because it is a language that everyone knows and everyone can connect with each other and be happy". He also says that he plays the guitar and spends most of his spare time in music room. He adds that he takes the same pleasure from English lessons especially when he actively takes part in classroom activities. He says that he learns English best when he is not aware of how the time passes just as he is performing music.

The forth student, PS4, is 11th grade student having high intermediate level in English (OPT:78). He explains his metaphor of "reading an adventure book" as follows: "English is like reading a new adventure book because studying English always brings me big and sudden changes, makes me excited and provides me new knowledge". He says that learning new words and phrases, especially idioms that very much enriches his scope to express his ideas in English makes him excited and motivated. The students commonly share the idea that every single unit in text book is a new adventure that brings them new sets of words and linguistic rules and ends up with a final which is the achievement test at the end.

In parallel with their positive metaphors on "English", all of these 4 students say that they not only take part in every English class but also go on reading, writing, listening to, watching, speaking, and practicing English outside the class, as well. PS2, constructing the metaphor of "playing games" says he always plays computer games which, he claims, teach him lots of vocabulary. PS3, resembling "English" to "music" says that he learns a lot from English songs and lyrics. In addition, PS4, perceiving "English" as "reading adventure books" advices his friend to read stage free 
fantastic and adventure novels, and to watch their movie versions especially in original version with English subtitles which improves his own English a lot.

The second focus group interview was with three students having negative perceptions on "English". The first student having negative view, NS1, is a 10th grade student with a low level of English (OPT:42). He explains his metaphor of "Azrael" as follows: "English is like Azrael because in every English exam I am in mortal fear and I feel like drowning". He confesses that he has always had hard time understanding English lessons and achieving English exams all throughout his English learning experience. He claims that his ongoing problems in English are all rooted from his lacking a proper background that he cannot make up for no matter how hard he studies. The other two students also agree that they usually get embarrassed when they are asked to answer a question orally or in pronunciation practices because of their deficiency especially in speaking skill.

The second student having negative view on "English" is a 9th grade student who has low intermediate level of English (OPT: 54). He constructed his metaphor as "English is like a torture because it becomes so boring because of wrong teaching methods". He says that he hardly takes proper scores from the exams, because he can never study properly for the exams. For him, a student should comprehend every single detail in the lesson if he wants to achieve his English exam. But as the lessons are taught very much based on course books in a monotonous and dull way, the students, especially the ones who have low levels in English, cannot learn it properly in class, therefore, cannot thoroughly get prepared for any exam. The other students agree that wrong methods of teachers can kill students' motivation and eagerness in English lessons. The first student also adds that the teacher's manner and approach towards the low level students is also very crucial. All the students put forward the common idea that a teacher should be kind and understanding especially when any low level student willingly participates in the lesson in order to maintain a high motivation and participation.

The third student, having negative view, is a 10th grade student who has also low intermediate level of English (OPT: 50). He constructed his metaphor as "English is like an ungrateful man because if you ignore it for a while, it forgets you". He emphasizes the significance of constant concern and cautious study which he says he can never achieve. Other students agree with him on the idea that English should be perceived as a living language which must be rehearsed and practiced constantly rather than one of the lessons which can be studied and achieved just before the exams. On the contrary, they say that they are never eager to participate in class or motivated in English lesson. They also never study English regularly and practice it outside the class. The researcher finds out that they are not very much interested in reading books, listening to English songs, and watching English movies, unlike their friends having positive perceptions.

Both of the focus group interviews were recorded on tape, carefully listened, transcribed and finally scanned by the researchers in order to locate the reoccurrences of the key words and concepts. These key concepts were grouped and interpreted in some main categories from which the following findings were generated and the central themes of discussion were derived:

\subsubsection{Students' Enjoying English Lessons}

The participants in metaphor study and focus group interviews are high school students in between the ages 14-17. They are in the ages that perceive the life as a constant joy and happiness. Furthermore, they live in an era of modern chaos in which they are stuck in tight schedules and strict curriculums. All the students having positive perceptions on "English" have an advanced level and don't have any problems in comprehending the lessons and achieving the exams. So, the mere thing that they want to find in any lesson, just like they want from the life itself, is to feel joy and happiness while trying to learn and adapt to a new set of information. They state that it is in the hands of teacher rather than the students. They claim that it is the teacher who can make a boring lesson a 50-minute period full of joy and fun.

\subsubsection{Students' Feeling Relaxed and Happy}

Learning can only occur in an atmosphere in which the learner feels free and comfortable to express himself and to take any part in classroom activities. all the participants having both positive and negative perceptions on "English" share the same idea that they can simply learn nothing, or learn and forget after a while if they are forced to learn under pressure or stress of doing mistakes, of being embarrassed in front of other students, and of being overloaded with the dull requirements firmly stated in curriculum and syllabus.

\subsubsection{Teachers' Approach towards Students}

According to the students who constructed negative views and had low levels of English, the teacher has a more crucial role in teaching. They said that students lacking proper level of English to understand and achieve the lesson are much more affected by their teachers' attitude towards them at class. They say that these students are in a crucial situation that with an understanding and positive approach of one English teacher, they feel motivated and eager to study more 
whereas they can probably abandon all efforts and quit trying anymore for English with a careless and strict attitude of teacher whom they defined as "Azrael".

\subsubsection{Teaching Method}

According to the students especially having negative views on "English", the teaching method of teachers plays a crucial role in low level students' learning experience. They say that it is not the linguistic methodology but the individual style and way of teachers in conducting lessons. They also claim that a teacher may present the lesson as a colorful and joyful entity with interesting audio-visual materials, especially short video clips about the subject matter which, they say, they very much like to watch, or may turn it to be a big disappointment even a "torture" for the students.

\subsubsection{Students' Lacking a Proper Background}

Two of the students having negative views on "English" state that their deficiency in English lessons roots back to their secondary school background. They say that as they don't have a proper linguistic background they can hardly add new knowledge or skill over it. They share the opinion that it takes time to improve their English to an upper level which they cannot manage among other students having high level in English.

\subsubsection{Students' Incompetence in Speaking and Pronunciation}

Students constructing negative metaphors on "English" say that when it comes to class participation and giving an oral answer asked in class, they have hard time to raise their hands and express their thoughts orally even they know the correct answer or have it written on their notebook. They claim that the reason is their deficiency in speaking, which is the most difficult skill to develop among others. One of them says: "Pronouncing some problematic words is another hard task we face during lessons, we feel shy when we make mistakes in front of others". In these ages, the teenagers sometimes become too impatient to tolerate their friends' mistakes. They are sometimes too much honest, objective, and even cruel that they criticize their friends' deficiencies which make the students having lower levels have hard times especially in oral practice and pronunciation.

\subsubsection{Regular Study-constant Concern}

The students having negative views are all aware of the importance of regular study and constant concern in English lessons which they never manage all through their English learning experience. For them, English lesson always requires constant, careful, and hard work as an "ungrateful man" that can forget you even after a short time you neglect him.

\subsubsection{Chances of Practicing English Outside the School}

The students having positive views on "English" are very much concerned with the other ways outside the school such as watching authentic films, listening to English songs, practicing with English lyrics, and reading English books to improve their English whereas the other group of students having negative views are not interested in anything related to English at all outside the school. Although they are aware of the importance of English in their life and of that they should study regularly, they perceive it only one of the lessons and forget all about it outside the class.

\section{Conclusion}

In the first stage of the study with the metaphors, conducted on 128 high school students and two focus group interviews held with students having positive and negative views on the concept "English", the aim was to find out any relation in between students perception of "English" and their participation and motivation in learning English. After the analysis of the data collected from metaphors, the followings conclusions can be derived:

- The high school students perceive English mostly as a gradual process which requires a definite time, effort, and patience. According to most of the students, English is a language that should be learned, and one of the lessons taught at school that could only be learned by constant concern and regular study.

- The high school students do not generally perceive English in global terms as a definite society or culture. For them, English is not commonly a language which is spoken by a definite nation or belongs to a definite culture. They do not perceive English as a national and political issue. Instead, they are more concerned with the English which is one of their lessons at school and one of their responsibilities in their individual world.

- The students both have negative and positive perceptions on English. However, with the specific data collected and analyzed in the study, it is concluded that the students tend to perceive English as a negative entity rather than positive, as they construct more negative metaphors on it. 
- The students' positive or negative perception of English and their level in English are two interdependent terms which are circularly related to each other. Students having advanced level in English tend to perceive English positively whereas the students having lower levels in English have rather negative perceptions on English.

The conclusions that can be drawn from the second stage of the research can be as follows:

- Students who have positive perceptions on English commonly construct the metaphors of "playing games", "music", and "reading adventure book" which are grouped under the conceptual category of "English as Joy and Fun".

- Students who have negative perceptions on English commonly construct the metaphors of "Azrael", "torture", and "ungrateful man" which are grouped under the conceptual category of "English as Fear or Hatred".

- Students who construct the metaphor of "playing games" commonly perceive English as a source of joy and fun. They also explain their metaphors as they get pleasure from studying and practicing English as they enjoy playing games. Moreover, the student who constructs the metaphor of "music" also perceives English as a fun and joyful activity. He explains his metaphor as he feels free, relaxed, and happy while speaking in English just as he feels while playing his guitar. In addition, the student who constructs the metaphor of "reading adventure book" perceives English as a fun and joy. The students also agree on the same idea that learning English provides them with different set of knowledge in each level as an adventure book makes the reader excited.

- Students conceptualizing English positively share the common point that English lessons should create an atmosphere full of joy and fun in which students feel themselves free, relaxed, and happy while improving their English.

- Students conceptualizing English positively are very much interested in the other ways of practicing and improving their English outside the school such as watching authentic films with English subtitles, listening to English songs, practicing with their lyrics, and reading English novels.

- The students having negative perceptions as "Azrael" share the common opinion that the problems they face in learning English root back to their improper background in English, and caused mainly by their incompetence in speaking skill. Moreover, the students who construct the negative metaphor of "torture" focus on the significant role of teacher and his constructive and positive approach especially to the students in lower level of English. They put forward that the teacher can contribute to his students level of English a lot with correct methods, and interesting audio-visual aids. The students who construct the metaphor of "ungrateful man" also emphasize the importance of constant and regular study in achieving an improved level in English which they always fail to do.

- Students conceptualizing English negatively are not concerned with the other possible ways of practicing and improving their English outside the school unlike the students having positive perceptions and higher level in English.

In conclusion, the students approach English language in the way as how they perceive it. In other words, students' positive or negative perceptions of English have a great influence over their motivation and willing participation in English class: Successful students who face no problem with understanding and using English and generally have positive perceptions about English show a great interest and motivation in classes. In contrast, the students of lower levels in English who tend to perceive English in negative terms have some critical problems in English which lead to further problems of low motivation and no participation. They don't have any eagerness or willingness to participate in class activities but prefer to remain silent in English lessons unlike the successful students who voluntarily play an active role in every English lesson.

\section{References}

Aristo (2008). Poetika. Trans. İsmail Tunal1 . Remzi Kitabevi, İstanbul, Turkey.

Aydin, İ. S., \& Pehlivan, A. (2010). Türkçe Öğretmeni Adaylarının “Öğretmen” ve "Öğrenci” Kavramlarına İlişkin Kullandiklarl Metaforlar (Turkish Studies International Periodical for the Languages, Literature and History of Turkish or Turkish), 5(3).

Balci, A. (1999). Metaphorical Images of School: School Perceptions of Students, Teachers and Parents from Four Selected Schools in Ankara. Middle East Technical University, Institute of Social Sciences, Ankara.

Bennett, M. J. (1997). How Not to Be a Fluent Fool: Understanding the Cultural Dimension of Language. In: A.E. Fantini (Ed.), New Ways in Teaching Culture (pp. 16-21). Alexandria, VA: TESOL.

Brown, H. D. (1994). Principles of Language Learning and Teaching (3rd eds). Englewood Cliffs, NJ: Prentice Hall Regents. 
Çelikten, M. (2006). Kültür ve Öğretmen Metaforları (Culuture and Teacher metaphors). Erciyes Üniversitesi Sosyal Bilimler Enstitüsü Dergisi, 21(2).

Eraslan, L. (2011). Sosyolojik Metaforlar (Social Metaphors). Akademik Bakış Dergisi. Uluslararası Hakemli Sosyal Bilimler E-Dergisi, (27).

Oxford, R. L., Tomlinson, S., Barcelos, A., Harrington, C., Lavine, R. Z., Saleh, A., \& Longhini, A. (1998). Clashing Metaphors About Classroom Teachers: Toward A Systematic Typology For The Language Teaching Field. System, (26).

Politzer, R. (1959). Developing Cultural Understanding through Foreign Language Study. Report of the Fifth Annual Round Table Meeting on Linguistics and Language Teaching, Georgetown University Press, Washington, D.C.

Saban, A. (2004). Giriş Düzeyindeki Sınıf Öğretmeni Adaylarının Öğretmen Kavramına İlişkin İleri Sürdükleri Metaphorlar (The Metaphorical Perceptions of Classroom Teacher Candidates Regarding Teacher and Teaching Profession Concepts). Türk Eğitim Bilimleri Dergisi, 2(2).

Saban, A. (2009). Öğretmen Adaylarının Öğrenci Kavramına İlişkin Sahip Oldukları Zihinsel İmgeler (The Metaphorical Perceptions of Classroom Teacher Candidates Student Concept). Türk Eğitim Bilimleri Dergisi, 7(2).

Sennett, R. (1980) Authority, New York: Vintage Books.

Sezer, E. (2003). Dilde ve Edebiyatta "Yol” Metaforu. Kitaplık, 65.

Shuell, T. J. (1990). Teaching and Learning As A Problem Solving. Theory into Practice, 29(2).

This work is licensed under a Creative Commons Attribution 3.0 License. 